\title{
Analysis of the nutritional composition of the typical meals of the rural workers in the Muanza District in Sofala - Mozambique
}

\author{
Arminda Uachisso ${ }^{1}$, Patrícia Padrão², Susana Carvalho ${ }^{3}$, Daniel Agostinho ${ }^{4}$, Olívia Pinho ${ }^{5}$
}

\begin{abstract}
1Pedagogical University, MZ (minderirene@yahoo.com.br), '2EPIUnit, Institute of Public Health, Faculty of Nutrition and Food Science, University of Porto, PT (patriciapadrao@fcna.up.pt), ${ }^{3}$ Faculty of Sciences, University of Porto, PT (susana.carvalho@fc.up.pt), ${ }^{4}$ Pedagogical University, MZ (agostinho.daniel@hotmail.fr), ${ }^{5}$ REQUIMTE, Faculty of Nutrition and Food Science, University of Porto, PT, (oliviapinho@fcna.up.pt) ORCID 0000-00019477-8638

https://doi.org/10.24840/978-972-752-260-6_0051-0055
\end{abstract}

\begin{abstract}
Introduction: Muanza district is located in Sofala province in central Mozambique, one of the poorest districts in the country. Here agriculture is the basis for the livelihood of many families, and their eating habits are based on products from their fields, especially cereals and tubers. The main objective was to characterize the dietary habits and the average nutritional intake of the peasants of Muanza and to propose adaptations to the habitual food in order to improve the adequacy of the nutritional intake of the population. Methods: The information about the usual dietary intake of the adult community living in Muanza was collected by observation for three days, typifying the three most frequent days in terms of dietary intake in the community. Foods were weighed, and the mean values of energy and macronutrients expressed in grams and contribution to the total energy value (TEV) were calculated using the Mozambican Food Composition Table. The nutritional composition of the "Nhakaka" (Dioscorea cayennensis) and "Minhanha" (Dioscorea rotundata) tubers was estimated by bromatological analysis. After analyzing the farmer's food nutritional composition, it was proposed improvements in their diet. Results: The structure of the daily dietary intake includes two meals per day. On day 1, one of the meals was composed of Yam (Dioscorea $s p$ ) and tea and the other included Xima (prepared meal of sorghum) and dried fish. On day 2, one of the meals was composed by Dioscorea cayennensis and tea and another included Xima and okra (Abelmoschus esculentus). On day 3, one of the meals was composed of Dioscorea rotundata and tea and the other included Xima and Nhemba beans (Vigna unguiculata). The average daily intake of energy was $1352 \mathrm{Kcal}$, the carbohydrate intake was $937 \mathrm{~g}(69.3 \%$ for TEV), fat was $100 \mathrm{~g}$ (7.3\% of TEV) and protein was $316 \mathrm{~g}$ ( $23.4 \%$ of TEV). When we increased the diet with seeds and fruits, daily energy would increase to 2125 Kcal, carbohydrates $1121 \mathrm{~g}$ ( $52.7 \%$ for TEV), protein $423 \mathrm{~g}$ (20\% for TEV), fat $582 \mathrm{~g}$ ( $27.3 \%$ for TEV). Conclusions: Muanza peasants had a low energy intake considering their pattern of physical activity, with a predominance of carbohydrates and very low fat. The average daily energy intake, as well as the fat intake, increases with the inclusion of seeds and fruits.
\end{abstract}

Keywords: Nutritional composition, Dioscorea cayennensis, Dioscorea rotundata, Rural workers.

\section{INTRODUCTION}

The Muanza district is located in the central Mozambique province of Sofala, one of the poorest districts in the country, with a poverty level of $67 \%$, according to data from the National Survey of Population Living Mozambique (Mussagy, 2014). Agriculture is the basis for the livelihoods of many of the district's rural residents in particular, and their eating habits are based on products from their farms, hence the menu of these families is basically low- diversified, high in carbohydrates. "Minhanha"(Dioscorea rotundata) and "Nhakaka" (Dioscorea cayennensis), are very consumed tubers in this region, although their domestication and cultivation is being done on a small scale, and their collection is done in the forest, unlike what happens in other regions of the Africa, where cultivation is practiced in large areas as part of the crop. Considering the physical activity exerted by the peasants and the expected monotony of the food intake, it is pertinent to know the nutritional intake of this population, in order to propose interventions that meet their nutritional needs.

\section{Objectives:}

- To characterize the usual diet and nutritional intake of peasants from Muanza district;

- To evaluate the nutritional composition of Dioscorea cayennensis and Dioscorea rotundata tubers used for food; 
- To propose adaptations to the habitual food in order to improve the adequacy of the nutritional intake of the population.

\section{METHODOLOGY}

The methodology was based on the direct observation, in Muanza, of the day-to-day food of 20 peasants. The conversion of food into macronutrients was performed using the food composition table of Mozambique (Korkalo, L. H., 2011). The energy value and the calculation of its contribution to the total energy intake (TEV) were then calculated. The typical consumed tuber samples which are locally known as "Nhakaka" (Dioscorea cayennensis) and "Minhanha" (Dioscorea rotundata) which were collected in Muanza district were submitted into bromatological analysis. The analysis were initiated by washing, weighing $300 \mathrm{~g}$ of the sample, slicing, drying in the shadow for a period of 10 days, and finally the grinding. The obtained flour was used for the bromatological analysis and the proteins were determined by the Kjeldahl method based on the determination of total nitrogen after the conversion factor 6.25; the fats were extracted by Soxhlet (solvent used as n-hexane) then removal of the solvent used; carbohydrates by the Munson-walker method; ashes by gravimetry; the determination of $\mathrm{Na}$ and $\mathrm{K}$ by flame photometry; $\mathrm{P}$ by colorimetry; and $\mathrm{Mg}$ and $\mathrm{Ca}$ by complexometry (first the determination of the $\mathrm{Ca}+\mathrm{Mg}$ set, for further subtraction to obtain the Magnesium content). After analyzing the nutritional composition of the usual food of the peasants, improvements in food intake were proposed in order to improve their nutritional adequacy.

\section{RESULTS AND DISCUSSION}

The observed daily food consumption (Table 1 ) was based on the consumption of food from their farms or harvested in the forest, with little food variety and low energy intake, given the physical activity exerted as peasants. The diet of these farmers was shown to be rich in carbohydrates but low in fat. The usual average daily intake of energy was $1352 \mathrm{Kcal}$, carbohydrate was $937 \mathrm{~g}$ ( $69.4 \%$ for TEV), fat was $100 \mathrm{~g}$ ( $7.3 \%$ of TEV) and protein was $316 \mathrm{~g}(23.3 \%$ of the TEV). With the inclusion of local foods such as fruits and seeds, the average daily energy will increase to $2125 \mathrm{Kcal}$, carbohydrates $1121 \mathrm{~g}$ ( $52.7 \%$ for TEV), protein $423 \mathrm{~g}$ ( $20 \%$ for TEV), fat $582 \mathrm{~g}(27.3 \%$ for the TEV) (Gomes, 2015). The proposal presented to obtain a diet relatively adequate to the work of the field increases the energy to $2125 \mathrm{Kcal}$, having increased the fats from $7.3 \%$ to $27.3 \%$, which significantly contributes to the energy reinforcement. Regarding the nutritional composition of the analyzed tubers (Table 2), these are a good source of carbohydrates that provide energy for the worker in the field but must be consumed with other foods that guarantee the supply of fats, proteins and micronutrients. The lipid content in Dioscorea rotundata was $0.78 \%$, similar to that found by Adepoju (2012), which was $0.8 \%$, regarding protein value, which was $7.5 \%$ higher than Adepoju's value (2012) of $2.3 \%$. For carbohydrates these were $70.49 \%$, and Adepoju (2012) for the same parameter found $3.3 \%$ for Dioscorea cayennensis the lipids represented $0.83 \%$ and the value found by Adepoju (2017) in the nine specimens analyzed was between 0.07 and $1.20 \%$; the value of protein $6.75 \%$ and Adepoju (2017) found values between 1.21 and 6.83\%; with respect to carbohydrates, we have 72.19\% for Muanza sample, and 17.08 to $37.26 \%$ for the analyses performed by Adepoju (2017). We can observe that the nutritional richness is different to highlight especially the carbohydrates that presented very high values when compared with the studies made by Adepoju in Nigeria. 
Table 1. Workers' food intake and diet improvement proposal

OBSERVED DIETARY INTAKE OF PEASANTS

\begin{tabular}{|c|c|c|c|c|c|}
\hline \multirow[b]{2}{*}{ DAYS } & \multirow[b]{2}{*}{ Foods } & \multicolumn{3}{|c|}{ NUTRITIONAL COMPOSITION } & \multirow[b]{2}{*}{$\begin{array}{l}\text { Fats g } \\
\text { (\%TE V) }\end{array}$} \\
\hline & & $\begin{array}{l}\text { Energy } \\
\text { (Kcal) }\end{array}$ & $\begin{array}{l}\text { Proteins } \\
\mathrm{g}(\% \mathrm{TEV})\end{array}$ & $\begin{array}{l}\text { Carbohydrates g } \\
\text { (\%TEV) }\end{array}$ & \\
\hline DAY 1 & $\begin{array}{l}\text { Dioscorea } s p \\
572 \mathrm{~g}, \quad \text { xima } \\
211 \mathrm{~g}, \quad \text { dried } \\
\text { fish } 161 \mathrm{~g}\end{array}$ & 1029 & $\begin{array}{l}583 g \\
(56.6 \%)\end{array}$ & $257 g(25 \%)$ & $189 \mathrm{~g}(18.4 \%)$ \\
\hline DAY 2 & $\begin{array}{l}\text { Dioscorea } \\
\text { cayennensis } 297 \mathrm{~g}, \\
\text { xima } 211 \mathrm{~g}, \text { nhemba } \\
\text { beans } 100 \mathrm{~g}\end{array}$ & 1422 & $\begin{array}{l}193 g \\
(13.6 \%)\end{array}$ & $1178 \mathrm{~g}(82.8 \%)$ & $51 g(3.6 \%)$ \\
\hline DAY 3 & $\begin{array}{l}\text { Dioscorea } \\
\text { rotundata } 412 \mathrm{~g}, \\
\text { xima } 211 \mathrm{~g} \text { okcra } \\
252 \mathrm{~g}\end{array}$ & 1604 & $\begin{array}{l}170 \mathrm{~g} \\
(10.6 \%)\end{array}$ & $1376 g(85.7 \%)$ & $57 g(3.7 \%)$ \\
\hline \multicolumn{6}{|c|}{ PROPOSAL TO INCREASE NUTRITIONAL INTAKE ADEQUACY OF PEASANTS } \\
\hline DAYS & Foods & $\begin{array}{l}\text { Energy } \\
\text { (Kcal) }\end{array}$ & $\begin{array}{l}\text { Proteins } \\
\mathrm{g}(\% \mathrm{TEV})\end{array}$ & $\begin{array}{l}\text { Carbohydrates g } \\
\text { (\%TEV) }\end{array}$ & $\begin{array}{l}\text { Fats g } \\
\text { (\%TEV) }\end{array}$ \\
\hline DAY 1 & $\begin{array}{l}\text { Dioscorea sp 572g, } \\
\text { xima } 211 \mathrm{~g}, \text { dried } \\
\text { fish } 161 \mathrm{~g}+100 \mathrm{~g} \\
\text { peanut, } 100 \mathrm{~g} \\
\text { banana }\end{array}$ & 1920 & $695 g(36 \%)$ & $629 \mathrm{~g}(33 \%)$ & $598 \mathrm{~g}(31 \%)$ \\
\hline DAY 2 & $\begin{array}{l}\text { Dioscorea } \\
\text { cayennensis } 297 \mathrm{~g}, \\
\text { xima } 211 \mathrm{~g}, \text { hemba } \\
\text { beans } 100 \mathrm{~g}+100 \mathrm{~g} \\
\text { sesame, } 100 \mathrm{~g} \\
\text { avocado }\end{array}$ & 2181 & $280 \mathrm{~g}(13 \%)$ & $1266 \mathrm{~g}(58 \%)$ & $636 g(29 \%)$ \\
\hline DAY 3 & $\begin{array}{l}\text { Dioscorea } \\
\text { rotundata } 412 \mathrm{~g}, \\
\text { xima } 211 \mathrm{~g} \text { okcra } \\
252 \mathrm{~g}+100 \mathrm{~g} \\
\text { pumpkin seeds, } \\
100 \mathrm{~g} \text { guava }\end{array}$ & 2274 & $294 \mathrm{~g}(13 \%)$ & $1468 g(64.5 \%)$ & $512 \mathrm{~g}(22.5 \%)$ \\
\hline
\end{tabular}

The average daily energy intake of the rural population of Muanza was low, considering the physical exhaustion during the performance of their activities. The diet is monotonous, low in fat and high in carbohydrates, and does not include vegetables or fruit. Luz, 2014, in his work on "Food consumption and working conditions in the manual cutting of sugarcane in the state of São Paulo" highlights the scarcity of studies with the population that works in sugarcane cutting, but recognizes the need to understand the nutritional and work aspects, to improve the protection of the workers and to prolong the time in the activity with health. It is necessary to adopt a diet that can provide energy for the work of the farm. The working conditions are not the best because they occur under average temperatures of approximately $30^{\circ} \mathrm{C}$ characteristic of that area of the Country in the summertime. "Among the information shared by the author, 
the average annual temperature of $24.5{ }^{\circ} \mathrm{C}$ stands out. The author also announces that January

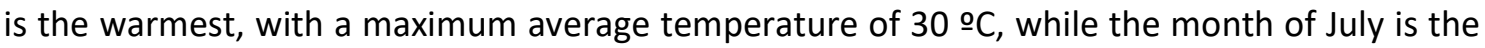
coldest, with a minimum average of 18 ㅇ." (Pacheco, 2009), which leads us to affirm that workers are subject to thermal stress since they are exposed to the sun for long periods, considering that the workday begins at five o'clock in the morning until approximately three hours of the afternoon. Abreu (2011), in his article on the production of sugarcane in Brazil and the health of the rural worker, describes similar working conditions to that of the workers at Muanza and in one of his conclusions affirms that excessive work hours, exposure to heat, inadequate food, unsafe transportation, financial devaluation, accident risks and psychological factors expressed in the form of discontent, stress and anxiety further aggravate the health of people working on sugarcane plantations. By making clear the precarious working conditions and the risks arising from field work, it is even worse if we are dealing with workers who do not have adequate food intake during work.

\begin{tabular}{llllllllllll}
\multicolumn{10}{c}{ Table 2. Nutritional composition of tubers } \\
Yam & $\begin{array}{l}\text { Energy } \\
\text { Kcal }\end{array}$ & $\begin{array}{l}\text { Protein } \\
(\%)\end{array}$ & $\begin{array}{l}\text { Carbohydrates } \\
(\%)\end{array}$ & $\begin{array}{l}\text { Fats } \\
(\%)\end{array}$ & $\begin{array}{l}\text { Ashes } \\
(\%)\end{array}$ & $\begin{array}{l}\text { Fibres } \\
(\%)\end{array}$ & $\begin{array}{l}\text { Ca } \\
(\mathrm{g})\end{array}$ & $\begin{array}{l}\mathrm{Mg} \\
(\mathrm{g})\end{array}$ & $\begin{array}{l}\mathrm{K} \\
(\mathrm{g})\end{array}$ & $\begin{array}{l}\mathrm{P} \\
(\mathrm{g})\end{array}$ \\
\hline $\begin{array}{l}\text { Dioscorea } \\
\text { cayennensis }\end{array}$ & 384 & 6.75 & 72.19 & 0.83 & 4.03 & 3.35 & 290 & 181 & 955.5 & 990 \\
$\begin{array}{l}\text { Dioscorea } \\
\text { rotundata }\end{array}$ & 385 & 7.5 & 70.49 & 0.78 & 5.17 & 2.3 & 0.25 & 212.5 & 1072 & 797.5
\end{tabular}

\section{CONCLUSIONS}

The peasant's workers in Muanza district have a usual low energy intake that does not guarantee the replacement of spent energy during its activity. The Dioscorea cayennensis and Dioscorea rotundata tubers cooked together with high-fat foods such as dried peanuts, sesame seeds, pumpkin seeds and the inclusion of local fruits can provide the worker with a diet with higher energy value, which would help to supply the physical activity resulting from its activity reducing the risks of the work accidents and increasing health and well-being.

\section{References}

Adepoju, O. T. (2012). Effects of processing methods on nutrient retention and contribution of white yam (Dioscorea rotundata) products to nutritional intake of Nigerians. African Journal of Food Science,6(6) 163-167.

Adepoju, O. T. (2017). Nutrient and Antinutrient composition of yellow Yam (Dioscorea cayenensis) products. ELSEVIER,v11, pp. 428-431.[Consult.a 02.04.2019] Available on

https://www.researchgate.net/publication/313816778_Nutrient_and_antinutrient_composition_of_yellow_yam_D ioscorea_cayenensis_products>

De Abreu, D., De Moraes, L. A., Nascimento, E. N., \& De Oliveira, R. A. (2011). A produção da cana-de-açúcar no Brasil e a saúde do trabalhador rural. Revista Brasileira de Medicina do Trabalho. v. 9, n. 2, p. 49-61. [Consult.a 04.04.2019]Available on <http://hdl.handle.net/11449/72967>

Gomes, S. J. (2015). Guia para uma alimentação saudável e ecológica. Porto: UPorto Edições.

Korkalo, L., Hauta-alus, H., \& Mutanen, M. (2011). Food composition tables for Mozambique. University of Helsinki: Helsinki, Finland. [Consult.a 04.04.2019]. Available on <https://ilsirf.org/wpcontent/uploads/sites/5/2017/03/Mozambique2011FCT.pdf >

Luz, V. G., Zangirolani, L. T. O., Vilela, R. A. D. G., \& Corrêa Filho, H. R. (2014). Food consumption and working conditions in manual sugarcane harvesting in Sao Paulo state. Saúde e Sociedade, 23(4), 1316-1328. 
Mussagy, I. H. (2014). Poorest Districts of Sofala Province and the Agricultural Production. Beira, Sofala, Moçambique. [Consult.a 10.04.2019].Available

on https://www.researchgate.net/publication/280113599_O_Nivel_de_Producao_Agricola_nos_Distritos_mais_Pobre s_da_Provincia_de_Sofala_Poorest_Districts_of_Sofala_Province_and_the_Agricultural_Production

Pacheco, J. A. A. Estratégias para sustentabilidade da flora bravia nas comunidades do distrito de Muanza, província de Sofala-Moçambique (Dissertação Mestrado, Universidade Estadual do Ceará, Centro de Ciências e Tecnologia, Fortaleza, 2009.117 p). 